\title{
RELIGIOUS WOMEN
}

\section{IN EARLY}

CAROLINGIAN

FRANCIA 
This page intentionally left blank 
FORDHAM SERIES IN MEDIEVAL STUDIES

Mary C. Erler and Franklin T. Harkins, series editors 
This page intentionally left blank 


\section{RELIGIOUS WOMEN}

IN EARLY

CAROLINGIAN

FRANCIA

A Study of Manuscript Transmission and Monastic Culture

FELICE LIFSHITZ 
Copyright (C) 2014 Fordham University Press

All rights reserved. No part of this publication may be reproduced, stored in a retrieval system, or transmitted in any form or by any meanselectronic, mechanical, photocopy, recording, or any other-except for brief quotations in printed reviews, without the prior permission of the publisher.

Fordham University Press has no responsibility for the persistence or accuracy of URLs for external or third-party Internet websites referred to in this publication and does not guarantee that any content on such websites is, or will remain, accurate or appropriate.

Fordham University Press also publishes its books in a variety of electronic formats. Some content that appears in print may not be available in electronic books.

Library of Congress Cataloging-in-Publication Data is available from the publisher.

Printed in the United States of America

$\begin{array}{llllllll}16 & 15 & 14 & 5 & 4 & 3 & 2 & 1\end{array}$

First edition 
To Qianguo

From Felice

You Became Quinn

You Made me Mommy

With Love

Hineni! 
This page intentionally left blank 